\title{
Volcanic Ash in the Atmosphere and Risks for Civil Aviation: A Study in European Crisis Management
}

\author{
David Alexander* \\ Institute for Risk and Disaster Reduction, University College London, London WC1E 6BT, United Kingdom
}

\begin{abstract}
This paper uses the eruption of the Icelandic volcano Eyjafjallajökull in April and May 2010 as a case study of disruption to civil aviation by airborne ash, with emphasis on risk management aspects. Severe curtailment of flights over much of Europe took place during the crisis, which lasted for slightly more than one week. More than 8.5 million passengers were stranded and commerce was profoundly affected. The United Kingdom was one of the worst impacted countries and took the lead in managing the crisis. The paper considers elements of the decision-making process that formed the basis of the UK Government's emergency response. It examines the relations between science, governance, and economic imperatives. Physical thresholds guiding decisions to restrict airspace were defined somewhat arbitrarily, which may have increased disruption. A damaging form of risk aversion prevailed at certain points in the crisis. Lack of preexisting procedures and planning meant that the response to dynamically changing meteorological conditions had to be improvised. At the same time, lack of integration between different modes in the European transportation system meant that had the crisis continued any longer there would have been severe problems in moving stranded people and commodities, as well as soaring economic losses. Eruptions similar to or more serious than that of Eyjafjallajökull are perfectly possible in Europe in the not-too-distant future.
\end{abstract}

Keywords Volcanic ash emergency, international civil aviation, crisis management, Europe, air transportation

\section{Introduction}

Worldwide there are some 1500 potentially active volcanoes, of which perhaps 50-70 erupt in any year (Siebert, Simkin, and Kimberly 2010). Not all eruptions are violent, as the nature of volcanic activity varies from relatively gentle outpourings of lava (effusive eruptions) to cataclysmic explosive events, termed ultra-Plinian eruptions (Sigurdsson 1999). However, even relatively mild forms of explosive eruption can inject particulate ash into the upper troposphere and lower stratosphere (Jakosky 1986). The smaller particles-glassy

\footnotetext{
*E-mail: david.alexander@ucl.ac.uk
}

silicates and aerosols - can remain suspended for days, weeks, or even years, and will drift with weather patterns and the prevailing directions of the general atmospheric circulation. If the concentration is sufficient, the ash may be a hazard to both aircraft in flight and airport operations on the ground.

Much has been written about the volcanology and meteorology associated with explosive eruptions and ash clouds (Leadbetter and Hort 2009). There is also a discrete literature on the nature of the hazard to jet aircraft and the whole system of civil aviation (Casadevall 1994a). Relatively little has been written about the organizational, logistical, risk management, and decision-making processes associated with volcanic ash emergencies for aviation (Casadevall and Krohn 1995; Guffanti, Casadevall, and Budding 2010). The eruption of Eyjafjallajökull (pronounced "A-ya-fyat-la-yœk-utl”) in Iceland in April 2010 provides a good opportunity to assess these aspects of such a contingency, and one that has not been extensively studied from this point of view. The crisis in the European transportation system that resulted from the collective decision by European air traffic control authorities to suspend commercial flights lasted hardly more than one week. Yet large numbers of people were affected and disruption during that time was severe-more so, in fact, than that caused by the "groundstop" imposed after the terrorist attacks of 11 September 2001 in the United States (Mazzocchi, Hansstein, and Ragona 2010). The economic costs were high and so was the level of uncertainty among the travelling public (including the present author). It is clear from the volcanological evidence that a larger eruption that injects far greater quantities of ash into the atmosphere for much longer periods is perfectly possible, with much more profound implications for travel in a continent as densely inhabited and as interdependent as Europe.

The purpose of this paper is to use the eruption of Eyjafjallajökull as a case study and derive some general lessons for crisis management from this example. I will begin by summarizing the nature of the hazard and risk. Next, I will consider the impact upon aviation and travel of the Icelandic eruption in April 2010. Then, I will examine some of the implications for crisis management and identify some lessons to be learned from this example. 


\section{Volcanic Ash Hazard to Civil Aviation}

This account is restricted to civil aviation and jet aircraft. Hazards to military fighter planes, turbo-prop aircraft and helicopters are regarded as a separate issue and are not considered here. ${ }^{i}$ In the case of Eyjafjallajökull, the most widespread risk was to the jet engines of commercial airliners. Airborne distributions of fine volcanic ash are not easily detectable by on-board weather radar. Whether they can be detected by ground-based and satellite means depends on the size and concentration of particulates. Other forms of remote sensing, such as LIDAR, may help atmospheric scientists to estimate the size, position, and ash concentration of plumes (Ajtai et al. 2010). A silicic volcano can inject ash into the stratosphere within five minutes of the start of a highly explosive eruption. Coupled with the dynamism of the earth's atmosphere, this leads to a mobile and rapidly changing hazard situation: ash is first concentrated and then dispersed in suspension at particular altitudes, typically between 7000 and 20,000 meters above sea level.

The risks to a commercial airliner stem from several sources and are well summarized by Miller and Casadevall (2000). First, air quality in the cockpit and cabin may be compromised by the intake of ash. Secondly, instrumentation may be damaged. This includes potential blockage of the Pitot tubes that measure speed in flight. The aircraft could stall if this information cannot be relayed to pilots (as occurred in the fatal crash of Air France flight 447 on 1 June 2009, when ice obstructed the Pitot tubes). Thirdly, forward surfaces, including the windshield, can be abraded by ash. Abrasion can also erode the compressor blades in the jet engines and thus reduce their performance. Finally, and perhaps most seriously, as jet engines operate at temperatures that are higher than the melting point of silica, ash can fuse onto surfaces within the engine, especially turbine vanes and parts of the combustion chamber. This can cause engines to flame-out and stall through loss of compression, although, as the aircraft descends, higher atmospheric pressures may allow an engine to be restarted.

According to international statistics, from 1935 until 2003 some 102 aircraft encountered atmospheric concentrations of volcanic ash that were dense enough to constitute a hazard to flight (ICAO 2007). The U.S. Geological Survey has formulated a scale to describe the severity of encounter in terms of the impact on the flying aircraft (see Table 1).

To date, no encounters of level five have occurred, although there have been several of level four. Two of these are particularly well-known. In the first case, on 24 June 1982, British Airways flight 9 from London to Auckland (Boeing 747-236B, registration no. G-BDXH) cruising at 11,000 meters, entered an ash cloud emanating from Indonesia's Galunggung volcano (Witham et al. 2012). All four engines surged and flamed out, whereupon the aircraft glided for 12 minutes and descended 7000 meters. The engines were
Table 1. Severity of encounter

\begin{tabular}{ll}
\hline Class & Description \\
\hline 0 & Acrid odor, electrostatic discharge \\
1 & Light cabin dust, EGT fluctuations \\
2 & $\begin{array}{l}\text { Heavy cabin dust, external and internal abrasion damage, window } \\
\text { frosting }\end{array}$ \\
3 & Engine vibration, erroneous instrument readings, hydraulic-fluid \\
& contamination, damage to engine and electrical system \\
5 & Engine failure requiring in-flight restart \\
& Engine failure or other damage leading to crash
\end{tabular}

Source: Adapted from Guffanti, Casadevall, and Budding (2010).

then restarted, but one of them failed again at 4000 meters. The aircraft nevertheless managed to land safely at Jakarta Airport, but as windshield abrasion had reduced the pilots' visibility almost to zero, it could not taxi off the runway. Moreover, smoke and dust were concentrated in the cabin and represented a health hazard to its occupants.

In the second instance, KLM flight 867 from Amsterdam to Tokyo (operated by Boeing 747-406 registration no. PH-BFC) flew into the ash cloud of Redoubt Volcano, Alaska. As the aircraft climbed to escape the cloud all four engines and the back-up electrical system failed. Battery power had to be used to restart the engines, and as this took numerous attempts, avionics and flight control systems were left without power. Two engines were restarted at 4000 meters and the remaining two at 3350 meters. Damage amounted to USD 80 million and all four engines were written off, although the aircraft continued to fly after major repairs (Casadevall 1994b).

These two incidents were widely discussed in the mass media at the time of the Eyjafjallajökull eruption (BBC News 2010). It is an open question how relevant these engine failure events were to the crisis in April 2010. Rather than catastrophic failure of engines in flight, there was a greater risk of abrasion damage to windshields and outer skins, and to turbine rotor blades and other engine components. The probable extent of this would depend on the configuration of ash clouds in relation to the pattern and frequency of flights.

Nonetheless, although the area around Eyjafjallajökull was interdicted to civil aviation, nowhere else had particularly dense concentrations of airborne ash. Paradoxically, Reykjavik International Airport (at Keflavik, west of Eyjafjallajökull) was not one of the most affected in Europe, as westerly winds blew the ash cloud away from it. For the rest of Europe there remained the question of when ash concentration was too great for safe flight. Despite various symposia and the publication of manuals on volcanic ash hazards to aviation (ICAO 2007), the answer was not known at the time (Brooker 2010). Moreover, this kind of hazard did not appear in the British Government's recently published national risk register (UK Cabinet Office 2010). 


\section{The Eyjafjallajökull Eruption of April-May 2010}

In the week 14-21 April 2010, 313 airports were closed in Europe, representing three quarters of the aviation network (Table 2). At the peak of the crisis, more than 75 percent of flights were cancelled (in total 108,000 throughout the week, or 48 percent of European air traffic - see Figure 1). The closures affected 10.5 million passengers, 8.6 million of whom were temporarily stranded. Economic damage resulting from inability to move passengers and goods amounted to somewhere between 1.7 and 3.3 billion euros (Mazzocchi, Hansstein, and Ragona 2010). So large was the socioeconomic impact that it prompts one to ask whether the decisionmaking processes that partly created it were appropriate and justified. However, first the event must be described.

Eyjafjallajökull, situated in the far south of Iceland, is not one of that country's most dangerous volcanoes. Nevertheless, it began to show signs of activity in December 2009 and suffered a flank eruption in March 2010. Explosive phreatomagmatic activity from the central vent began on 14 April 2010 and continued, sporadically, until 22 May (Figure 2). During the early days a $9 \mathrm{~km}$-high plume of ash was emitted from the central vent. The emission of ash was sufficient to provoke a six-day closure of northern and central European air-space over the period 15-20 April, as well as further partial closures in May. Yet, in volcanological terms, this was not a large eruption: it reached $\mathrm{VEI}=4$ on the volcanic explosivity index, which involved the emission of about $1 \mathrm{~km}^{3}$ of magma-equivalent (Newhall and Self 1982). In comparison, the 1815 eruption of Tambora in Indonesia (VEI=7), the largest volcanic event in the last two centuries, emitted more than $100 \mathrm{~km}^{3}$. The last eruption of Eyjafjallajökull before 2010 lasted from December 1821 until January 1823, including 25 days of continuously heavy ash emissions. One can hardly begin to imagine what 13 months without air travel in Europe would be like. Moreover, other Icelandic volcanoes (notably Katla, Hekla, and Krafla) have a higher eruption potential than Eyjafjallajökull (Sammonds, McGuire, and Edwards 2010).

Experience from around the world clearly indicates that volcanic eruptions function according to geological rules, not human dictates. This means that the timing of events can be unpredictable, despite an increasingly precise ability to monitor fluxes of heat and gases, deformation of the ground, and volcano seismicity. It also means that the sequence of an eruption can be prolonged and irregular. Mount Vesuvius in southern Italy erupted continually from 1631 to 1904, with never more than seven years' interval between emissions. Hence the onset and duration of an eruption may be difficult to foresee in any way that can benefit emergency management.

The upshot of this is that authorities may have to devise solutions to problems caused by natural events whose beginning, evolution, and ending are uncertain and at best only partly predictable. This requires a high degree of flexibility and ingenuity, as well as clear and well-conceived rules about

\section{Table 2. Chronology of the Eyjafjallajökull eruption crisis}

Wednesday, 14 April 2010 (Day 0)

$\$ 28,087$ flights take place in Europe (1.3 percent more than the previous Wednesday)

\$ Eyjafjallajokull begins to erupt at 07:00 hrs Central European Time (CET) and the first advisory is issued at 10:13 hrs

$\$ \quad$ Norway and Scotland restrict air space, Sweden and Finland do so from midnight

Thursday, 15 April 2010 (Day 1)

\$ 20,842 flights take place in Europe (a 27.1 percent decrease)

$\$$ airspace closures gradually affect almost the whole United Kingdom

$\$$ airspace closed in Denmark and Ireland, and from 15:00 CET in Belgium, the Netherlands, and southern Sweden

$\$$ additional regulations applied in Sweden and Norway

Friday, 16 April 2010 (Day 2)

$\$ \quad 11,659$ flights take place in Europe (a 59.2 percent decrease)

$\$$ airspace closes in Germany and eastern and southern European countries

Saturday, 17 April 2010 (Day 3)

\$ 5335 flights take place in Europe (a 76.5 percent decrease)

$\$$ airspace closures spread across Estonia, Poland, Switzerland, the Czech Republic, Austria, Hungary, Romania, Ukraine, France, Germany, and northern Italy

\$ plans to reopen parts of UK, Dutch, and German airspace do not prove feasible

Sunday, 18 April 2010 (Day 4)

\$ 5204 flights take place in Europe (a 79.2 percent decrease)

$\$$ at 16:00 CET airspace is open above 6000 meters in the Bremen, Maastricht, and Rhein areas and in Austria, France, Italy, Poland, Spain, and Switzerland

Monday, 19 April 2010 (Day 5)

\$ 9330 flights take place in Europe (a 66.8 percent decrease)

\$ some flight sectors open in Germany, France, the Czech Republic, Romania, Slovakia, Switzerland, Ukraine, Spain, Bulgaria, and Austria

Tuesday, 20 April 2010 (Day 6)

$\$ \quad 13,101$ flights take place in Europe (a 52.4 percent decrease)

$\$$ new Eurocontrol procedures enter into force at 06:00 CET

$\$$ most airspace is reopened except the UK, which reopens at 20:00 CET

Wednesday, 21 April 2010 (Day 7)

\$ 21,916 flights take place in Europe (a 22.0 percent decrease)

$\$$ by 09:30 hrs CET most European airspace opens except in parts of northern Scotland, Sweden, Finland, and northwest France

Thursday, 22 April 2010 (Day 8)

\$ 27,284 flights take place in Europe (a 4.5 percent decrease)

$\$$ the aviation emergency concludes, pending any further developments of the eruption

Source: Eurocontrol (2010)

the conditions under which flights can take place. The problem with Eyjafjallajökull was that the rules were worked out, with significant and perhaps arbitrary changes, in an ad hoc manner during the course of the emergency.

\section{Consequences of the Eruption}

Airspace closures began at midday on Thursday 15 April 2010. They were accompanied by the progressive closure of 


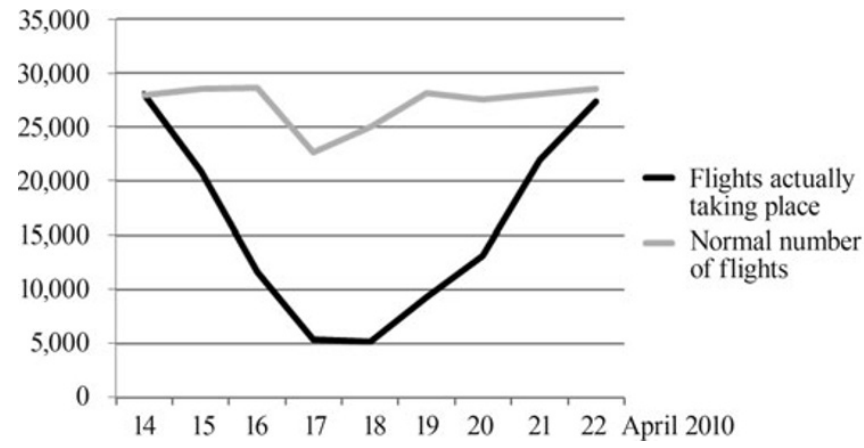

Figure 1. Flight cancellations in Europe over the period 14-22 April 2010 compared with normal levels of air traffic Source: Eurocontrol (2010).

more and more airports. The United Kingdom took the lead in this process, informed by the London branch of the International Airways Volcano Watch (IAVW-Romero 2004), which liaised with the UK's National Air Traffic Control Service (NATS). Other countries in northern and central Europe soon followed suit. By 17 April airports were closed as far south as Rome and as far east as Moscow. In Europe only certain Iberian airports escaped closure. It was 22 April before normal service was-partially and tentativelyresumed, by which time an enormous backlog of stranded passengers had built up. In the worst cases, it took up to three weeks to accommodate some of the people who needed to fly from parts of Asia and South America to Europe. It has been suggested (The Guardian 2010) that this was the result of airlines' restriction of the availability of seats to stranded long-haul passengers. If that is so, it reflects the airlines' desire to sell more seats and make up for the deficit caused by the interruption of business.

In all 108,000 flights were cancelled, lost revenues amounted to USD 1.7 billion and 10.5 million passengers had their travel plans disrupted (Budd et al. 2011). The economic consequences for business included not only reduced passenger receipts, but also blockage of the movement of goods. More than one fifth of the economy of Kenya consists of exporting flowers to Europe, and that trade ceased for the duration of the flight ban. As a result, more than one million roses had to be destroyed. Other consequences included lifethreatening delays in the importation of bone marrow from donors in North America to patients waiting for transplants in Europe. In this respect, the Eyjafjallajökull crisis calls to mind the unanticipated consequences of the terrorist attacks on the United States on 11 September 2001: for example, the small town of Gander, Newfoundland, suddenly had to spend a week caring for the occupants of 36 wide-bodied passenger aircraft that had been forced to land there when the U.S. aviation authorities imposed a blanket "groundstop" (Scanlon 2003).

As expected, many of the stranded passengers turned to other forms of transport to get home from holidays and business trips, in some cases with surprising ingenuity and versatility (Jensen 2011). This put considerable strain on the European train and ferry network. Hotel prices in some of the major continental cities soared, while in other places hotels were unusually empty. Particular problems were experienced by people, such as students, whose economic means were limited and who found themselves unable to afford accommodation, yet they were not supported by the air carriers from

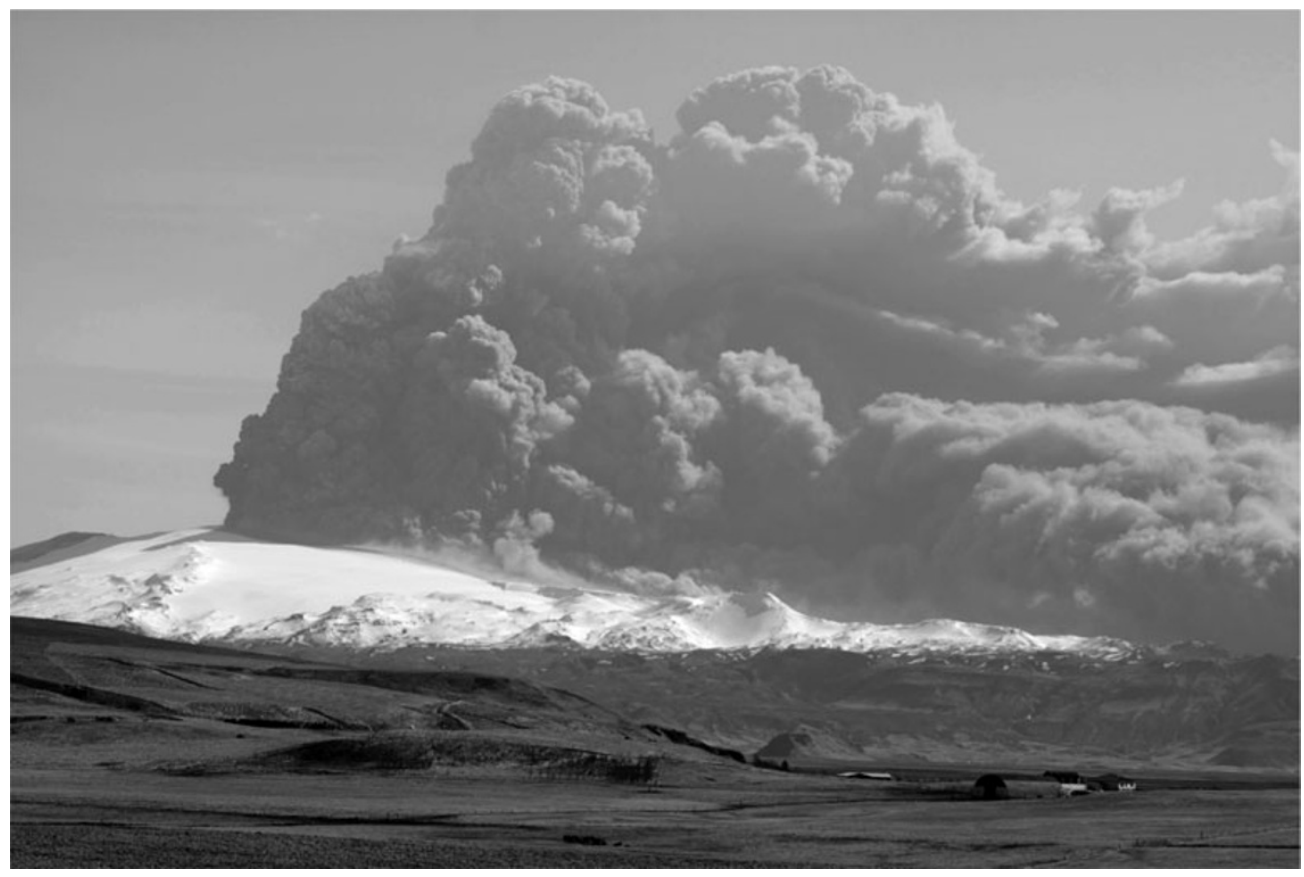

Figure 2. Eyjafjallajökull in eruption, April 2010

Source: Wikimedia Commons. 
whom they had purchased tickets. It was thus common to find such people sleeping in airport terminals, which were otherwise devoid of passengers and personnel. Meanwhile serious overcrowding occurred at railway stations and on long-distance trains. Most stranded passengers experienced substantial delays and had to pay significant additional costs to reach their destinations. The prices of ground travel- for example, on the cross-Channel Eurostar trains - rose to meet the vastly increased demand, but capacity remained relatively inflexible, and quite inadequate.

European Commission regulation 261/2004 came into force in February 2005 and is designed to guarantee air passengers' rights in the event that they are unable to travel for any reason that is out of their control, such as overbooking or cancellation of a flight (European Union 2004). It was obviously intended to counter commercial arbitrariness and exploitation of passengers by the airlines, and it was immediately opposed by IATA and the European Low-Fare Airlines Association (ELFAA). During the Eyjafjallajökull crisis, the guaranteed right to compensation and material assistance was vigorously contested, especially by the low-cost carrier RyanAir, whose CEO, Michael Ryan, did not see why a passenger who had paid very little for a flight should be substantially compensated when it had to be cancelled for reasons that were beyond the control of the airline. The legislation was clearly not framed in the light of a major natural event and ELFAA members felt that, while it might be reasonable in the case of single cancellations, it imposed an unfair burden on them during a major and prolonged European crisis. Because a natural calamity was beyond their ability to control, airlines maintained that no liability could be established. However, the real matter at stake was the question of who bears the risks associated with not being able to travel as expected. Nonetheless, the European Commission refused to back down, arguing that if airlines carried passengers they had a responsibility not to abandon them. RyanAir attempted to test the Commission's resolve by not paying out and was duly fined. In fact, in a series of rulings issued between March 2012 and January 2013, the European Court of Justice confirmed the company's obligation to compensate stranded passengers, some of whom had sued (The Guardian 2013; European Court of Justice 2013).

\section{Official Responses to the Eruption}

In 1947 the Icelandic volcano Hekla erupted with a larger emission of airborne ash than the 2010 event at Eyjafjallajökull. Since then civil aviation has grown enormously in scope and importance to daily life. By 2007, when the fourth international conference on volcanic ash hazards was held in New Zealand, it was recognized that improvements in remote sensing enable ash clouds to be tracked more precisely. Despite such innovation, knowledge of ash clouds poses operational questions for civil aviation that, if not resolved satisfactorily, could lead to high losses of revenue without corresponding benefits of safety when air travel is shut down. One thing which is not in doubt is that in April 2010 volcanic ash hazards to air transportation had been well known for decades (Scarone 1987).

I now focus on decision making in the United Kingdom, which was the country that took the lead in air transportation management during the crisis, no doubt because of its relative proximity in the North Sea to Iceland and thus its location in the path of the ash cloud. The main question to answer is whether the UK response, and the subsequent response in the rest of Europe, were justified by the risks or whether the response should have been different? In other words, should commercial flying amid suspended particulates of volcanic ash be avoided at all costs, or is there a reliably detectable level at which the risks of damage or equipment failure in flight for any given periods of time are insignificant? Furthermore, if the latter case prevails, what is the safe threshold level of ash concentration in the atmosphere? Finally, what are the consequences if air transportation shuts down and what alternative strategies can be used to mitigate them?

The London Volcanic Ash Advisory Centre (LVAAC) was set up in the 1990s by the International Civil Aviation Organization (ICAO). At midday on Thursday 15 April 2010 the UK National Air Traffic Control Service (NATS) responded to a warning notice from LVAAC by banning all non-emergency traffic in UK airspace. It is important to note that identification of the distribution and concentration of suspended ash particulates requires a combination of methods, including satellite remote sensing with LIDAR, ceilometers and ground-based sun photometers (Krotkov et al. 2010; Flentje et al. 2010). The results may be solid scientifically, but they are somewhat equivocal about the effects on jet aircraft. The LVAAC issued maps that offered no data on concentration levels, other than defining the edges of the cloud by the $200 \mu \mathrm{g} \mathrm{m}^{-3}$ isopach. The LVAAC was slow to utilize the U.S. Geological Survey's color coded warning (Casadevall 1994a), which is a standard form of reference for American volcanological observatories when they need to communicate with civil aviation and meteorological authorities (Albersheim and Guffanti 2009).

The British government entered the crisis with no reliable data on ash concentrations in the European atmosphere and none on levels at which it was safe to fly. The result was a form of risk aversion, which prevailed until better information was made available. Initially, flights were banned in areas delimited as being covered by the ash cloud (at least $200 \mu \mathrm{g} \mathrm{m}^{-3}$ ). By 20 April, the threshold had been raised by one order of magnitude to $2000 \mu \mathrm{g} \mathrm{m}^{-3}$. It appears that very serious damage to jet engines begins at concentrations approaching three orders of magnitude higher $-2 \mathrm{~g} \mathrm{~m}^{-3}$. Around the $2000 \mu \mathrm{g} \mathrm{m}^{-3}$ level an "enhanced procedures" zone was established where limited flying could take place, buffered with a 60 nautical mile (approximately $111 \mathrm{~km}$ ) interdiction zone. The latter was abolished on 11 May, when a form of "enhanced procedures" zone was introduced that allowed short flights in the area bounded by the 2000 and 
$4000 \mu \mathrm{g} \mathrm{m}^{-3}$ isolines. Despite its possible arbitrariness in terms of air operations, this distinction was later institutionalized in the ICAO volcanic ash contingency plan, a post hoc set of general procedures for assessing and dealing with the risks posed by eruptions to aviation (ICAO 2010b). The plan followed ICAO task force meetings in Montréal in July 2010 in which it was noted that ash concentration thresholds had never been established before Eyjafjallajökull, but that further research was needed in order to establish how valid the proposed ones actually are (ICAO 2010a). This, of course, is risk management without adequate knowledge of vulnerability and risk - and potentially on a continental scale!

The British Government's penchant for risk aversion was amply demonstrated in a previous case, that of the Hatfield train crash of 17 October 2000. This high-speed rail accident killed four people and resulted from a broken rail, or technically "rolling contact fatigue" leading to "gauge corner cracking." Railtrack, the British rail engineering company, immediately imposed 1200 speed restrictions of $30 \mathrm{~km} \mathrm{hr}^{-1}$ on the national network and allowed them to persist for months until full inspections had been carried out all over the country. The result was a slow-down in trains that led to the virtual forced abandonment of the national timetable. The disruption was extreme and prolonged, and Railtrack was eventually declared bankrupt. Many observers questioned whether such a cautious approach was necessary: it led to highly expensive disruption, but not necessarily to great improvements in safety (Jack 2001).

The dynamics of atmospheric circulation could cause relatively large changes in the pattern of ash concentration in only a few hours. Hence the concept of "safe corridors"-widely discussed during the Eyjafjallajökull crisis-is called into question. This involves connecting departure and destination airports with flight paths that are free of significant hazard. Unfortunately, if an abrupt change in weather patterns should occur, one can envisage a corridor being closed while it is being used.

There were several questionable aspects of the United Kingdom's strategy for managing the crisis. First, as volcanic ash aviation emergencies do not appear in the 2010 edition of the National Risk Register (UK Cabinet Office 2010), there was no anticipation of the needs posed by the emergency, and thus the response was purely reactive. The UK's emergency management system is based on a command and control model in which "gold," "silver," and "bronze" correspond respectively to strategic, tactical, and operational commands (Arbuthnot 2008). The top of the pyramid is represented by "platinum," sometimes known as "diamond," which in effect is the Cabinet Office Briefing Room (COBRA), the national policy and strategy committee under the nominal leadership of the Prime Minister. COBRA first met at 08:30 hrs on Monday 19 April, almost four days after the start of the crisis. Notwithstanding anything that may have gone on behind the scenes, this showed a lack of visible leadership at a time when travellers, airlines, and other interested parties were perplexed about the situation and unable to see a way forward.
This passive "wait and see" approach was not greatly appreciated by the public. It was mirrored by Eurocontrol, the European Organization for the Safety of Air Navigation, which did not move towards a harmonized approach until impelled to do so by the European Commission at a meeting held on 19 April, well into the crisis (Brannigan 2010). Until that point, and to a lesser extent afterwards, the response was characterized by nations that took the initiative in making decisions and other countries that followed them, prompting one expert on risk regulation to comment that "EU integration does not yet extend to air traffic management" (Alemanno 2010). The situation was somewhat corrected in the publication eight months later by the International Civil Aviation Organization of the regional volcanic ash contingency plan (ICAO 2010b). This document specifies unsafe levels of atmospheric ash concentration, using the thresholds that were employed at the end of the April 2010 crisis, and defines the conditions for issuing bulletins to aviation personnel, including pilots. But the ICAO does not define or apportion the responsibilities for declaring interdiction zones for civil aviation in Europe.

Secondly, there was an initial failure to realize that detailed information on ash concentrations was needed. The cloud did not constitute a uniform hazard to aviation. The thresholds selected (200 and $2000 \mu \mathrm{g} \mathrm{m}^{-3}$ ) did not have an adequate justification in terms of science or flight engineering. After more than 10 years of development of high-resolution Lagrangian convection-diffusion models, the UK Meteorological Office supplied ash-cloud monitoring and prediction data using its Numerical Atmospheric-dispersion Modelling Environment (NAME III) digital model (Jones et al. 2007), the original version of which was developed to track the diffusion of radionuclide pollution from Chernobyl. This was criticized as inappropriate (Sammonds, McGuire, and Edwards 2010, 10), but there were few alternatives. At the same time, agreements had been reached with aircraft engineers and the manufacturers of jet engines on safe concentrations. It was not until the week after the crisis started that experimental flying began for the purposes of collecting ash concentration data in airborne filters and testing the effects of particular concentrations on jet engines and the aircraft on which they were mounted. The experiments involved a research aircraft that flew from Cranfield University Airport in Bedfordshire, England, to Glasgow and back on 20 April. It was followed by a British Airways Boeing 747 that flew from Bristol to Scotland and back, largely as a provocation to the British Government, as British Airways was concerned about its losses. Similar pressure to lift the ban had already come from German airlines Lufthansa and Air Berlin. The results of the flight tests were encouraging enough for interdictions on flights progressively to be rescinded.

It is clear from this description that some of the fundamental ingredients of the decision-making process could only be acquired during the crisis. These included meteorological and ash concentration data. Others should have been available before it happened. They included information on safe levels 
of tolerance of suspended volcanic ash particulates for aircraft skins, jet engines, avionics, instrumentation, and cabin air quality. Finally, no procedure was in place to make the relevant decisions. The result was managerial improvisation when it was least warranted. This constituted a precautionary approach that bordered on risk aversion and had little scientific or engineering justification.

\section{Pan-European Approaches and Problems}

Eurocontrol, the European Organisation for the Safety of Air Navigation, is a civil agency with 39 member states. It is not an organ of the European Union with which it collaborates closely. Its aim is to achieve greater interoperability and efficiency together with better safety management in European aviation. But the lengthy 2006 Eurocontrol report on risk management (Eurocontrol 2006) makes no mention of volcanic eruptions or other natural hazards (neither does the 2010 edition of the UK Government's risk register). It concentrates entirely on general accident prevention measures. Eurocontrol cannot override national air transportation management or policy. Nor can it countermand European Union initiatives. With regard to these, the disruption caused by the ash cloud led to an acceleration of the EU's Single European Sky initiative, which is designed to coordinate the management and regulation of airspace across Europe (Schubert 2003). In fact, the Single European Sky Air Traffic Management Research program (SESAR) is being progressively implemented by Eurocontrol members. SESAR's aim is to improve safety, efficiency, and interoperability by introducing a uniform system to what were previously disparate initiatives by the various national air traffic management agencies (Graham and Young 2006). This is taking place in the context of the development of the European Common Aviation Area, in which $27 \mathrm{EU}$ countries and nine other nations had signed an agreement to guarantee common aviation services (Schubert 2003).

There are many organizations and initiatives that have a stake in managing access to the European skies. Thus the regulatory situation is complex and has many possible consequences, not all of which are immediately clear (Button 1996). For example, liberalization and efforts to promote greater interconnectedness have undoubtedly increased the range of options for Europe's travellers. However, national air space remains sovereign: it can be coordinated by supranational bodies, but these cannot countermand national decisions. Moreover, increased competition has led to crowded skies and service providers that operate on small profit margins (Nippani and Washer 2011). The result is a curious mixture of fragmentation and integration (Alemanno 2010). It is of note that none of the international programs seeks to integrate air travel with other forms of transportation, which are assumed to be in competition with civil aviation. Opportunities for a fully integrated response to emergency logistics are thus quite limited.

\section{Logistical Aspects of the Crisis}

Apart from deciding whether it was safe to fly or not, decisions needed to be made that ensured other forms of transportation were available in substitution. Seven million people were stranded across Europe and pressure on trains, buses, coaches, taxis, and vehicle hire was intense. While some places had spare hotel capacity (London, for instance), others (such as Paris) rapidly developed acute shortages of accommodation. Pricing was left to the operators to regulate, and many of them instantly perceived an opportunity to profit by the crisis.

When it appeared that flights might not resume for some time, COBRA began to make plans for mass transportation. This would have involved collecting passengers at a hub airport which remained open, such as Madrid, conveying them by road to the port of Santander, and putting them on naval ships. This strategy was actually carried out for members of the UK armed forces returning from duty in Afghanistan. It was tacitly agreed that spare capacity on HMS Albion would be given to civilians in need, although for fear of stimulating greater demand than could be accommodated, that was not widely stated to the public. Had the crisis continued for much longer, there would have been a need for significantly greater intervention of this kind. People returning to Europe by air from the Americas would have had to land in Spain and proceed by land or sea. The concept of sea travel was sound, since it would have helped alleviate congestion on Europe's railway network. But it had some drawbacks. Most countries looked after their own nationals abroad through their international diplomatic representation. Emphasis was placed on getting people back to their countries of origin. As any expat knows, not all essential travel involves return to one's country of citizenship. At a time of severe rationing of places on means of transport, certain groups of people might not receive help.

The travellers' tales that came out of the crisis highlighted the fact that there is precious little integration between modes of transport in Europe. That is especially true in terms of crisis response. The disappearance of air traffic did not mean that other modes of transportation (ferry, coach, rail, etc.) could combine efficiently to take up the excess demand. This was especially problematic for long-distance travel, which, without aircraft, required a greater than normal combination of modes. The root of the problem lies in the question of sovereignty versus federalism in Europe. Policy and operational decision-making for air traffic and other forms of transportation occur at the national level, which is logical in terms of sovereignty but may complicate matters for international travel, which requires a harmonized approach. What is clear is that Europe badly needs crisis response strategies and plans that provide for substitution if one mode of international transport fails. Such plans should maintain affordable prices at the same time as they enhance both the capacity and the efficiency of mass transportation over long distances and across national boundaries. 
As with so many other forms of emergency planning, so with volcanic ash and civil aviation, it is necessary to consider the secondary and collateral effects that must be dealt with. For example, for some types of commerce, face-to-face meetings can be substituted by video conferencing and other kinds of electronic networking. Other forms need careful evaluation of alternatives and development of contingency plans. Special attention needs to be given to what to do about flying for emergency purposes. If rescue missions cannot be flown, or essential medical supplies cannot be air-freighted, what are the alternatives in terms of guaranteed priority delivery of the service in question?

\section{Discussion}

An influential report by University College London's Institute for Risk and Disaster Reduction concluded as follows:

The ban on flights not only meant increased risks for all those travelling by other means; it also threatened the livelihood of whole economies. Once the appealing simplicity of the precautionary approach breaks down, an array of difficult questions arises, including: which risks (and which benefits) ought to be taken into account? Who is to articulate the values (beyond safety) that ought to be addressed when managing risks? (Sammonds, McGuire, and Edwards 2010, 14)

It also commented that:

The havoc arising from the eruption of Eyjafjallajökull has been presented in many circles as being a consequence of the event being both unprecedented and unexpected-neither is the case. (Sammonds, McGuire, and Edwards 2010, 8)

Part of the report comprised a detailed critique of the use of the ALARP (as low as reasonably possible) risk management approach (Melchers 2001). Initially, this made use of the two thresholds, 200 and $2000 \mu \mathrm{g} \mathrm{m}^{-3}$, as representative of broadly tolerable and unacceptable risk levels. In reality, neither value had a scientific or operational basis; hence both were entirely arbitrary foundations of decisions that had widespread socioeconomic repercussions. Regarding the economic impact of the crisis, Nippani and Washer (2011) found that investment in European airline stocks fell as a result of the eruption. Paradoxically, Mazzocchi, Hansstein, and Ragona (2010) estimated that the financial losses to the airlines caused by the first week of the emergency were insignificant, but in contrast after one month the cumulative effect was enormous - in fact, they estimated it to be 3.3 billion euros for nine European flag carriers, about twice some of the initial projections for the entire civil aviation industry. This reflected the effect of uncertainties and recurrent obstacles to flying and suggests that a longer drawn-out eruption scenario could very easily send companies rapidly into bankruptcy.

Prudent emergency management is necessary in order to avoid losses wherever that is possible. It is a question of finding equilibrium between three essential ingredients: procedures and protocols, plans and planning, and improvisation (Alexander 2002). Inefficiency is manifest by excesses of improvisation when what is being improvised could - and should - have been foreseen and decided upon in advance. The British Government's passive and reactive approach to the Eyjafjallajökull crisis betokened improvisation and reaction, rather than foresight and prior planning. Regardless of whether politicians, civil servants, emergency managers or scientists were to blame, the country was not ready to tackle a foreseeable emergency, which took it entirely by surprise. Given the large amount of information that was available at the time in the atmospheric and earth sciences, and the increasing sophistication of volcanological and meteorological remote sensing monitoring processes, this lapse is not entirely comprehensible and one hopes that it will not be repeated.

Further investigation is needed with regard to the processes of international decision making. Through ICAO and the International Airways Volcano Watch, there are potent mechanisms for information sharing between European nations. However, the vast majority of the data inform decision making at the national rather than the continental level (ICAO 2010a, 2010b). Countries do tend to follow suit when one of them takes the lead (in April 2010 it was the United Kingdom). Still the response to Eyjafjallajökull was nonetheless fragmentary and it did little to coordinate movement through the European transportation network. With low-cost airlines and the gradual development of a continental highspeed rail network, international travel is becoming ever more common and popular. It demands a comprehensive process of emergency planning, and one that facilitates modal switch by being able to manage emergency capacity at the transnational level, as noted in a recent document from the European Commission $(2010,7)$.

After the terrorist attacks of 11 September 2001 in the United States, the popularity of flying plummeted among the general public, which took to the roads. For more than two years the number of road accident casualties was higher than normal, while during the same period there were no fatalities as a result of commercial aviation (Gigerenzer 2006). This reminds one that a risk analysis for cessation of flights should also take into consideration the possibility of risk transfer, which needs to be weighed against the risks of allowing flights to take place. The methodology should also bear in mind that people do not necessarily see each death as being equal, as there may be greater tolerance for mortality on the roads than for deaths in civil aviation (Viscusi 2010).

The management of volcanic emergencies requires careful and detailed use of scenarios. In this context a scenario can be defined as the projection into the future of possible alternative sequences of events in order to plan flexible responses (Schoemaker 1993). Properly used, scenarios can constrain uncertainty and increase confidence in projections. The scenario for ash-cloud interruptions for civil aviation should take account of transportation problems, interruption of business 
activities, possible cessation of essential activities (especially in the medical field), and risks of bankruptcy in key sectors of the economy. The economic, social, and logistical consequences need to be estimated for differing durations of the emergency and strategies to reduce impacts should be put forward. Although difficult, this is not impossible.

In this paper the April 2010 Eyjafjallajökull volcanic emergency has been considered through a retrospective evaluation. It is by no means unique and could easily be repeated, potentially on a more spectacular scale. One may expect an explosive eruption from Iceland on average every five to seven years (Sammonds, McGuire, and Edwards 2010). Twenty eruptions in historic time have been between one and two orders of magnitude larger than the Eyjafjallajökull 2010 event, with eruption columns two to three times higher. In recompense, the north-westerly wind patterns that would blow ash across Europe occur perhaps only six percent of the time. Volcanic emergencies can involve long sequences of activity. For example, in the Caribbean, Montserrat began its present eruptive cycle in 1995 and is still not quiescent, necessitating the semi-permanent evacuation of some of the islanders. Prolonged uncertainty is the enemy of strategic and tactical decision-making, but at least it can be constrained by the use of scenarios. A further remedy is to have flexible procedures and broad, all-embracing plans that are prepared before any such emergency with a clear idea of some of the options that might have to be faced when it happens. Three examples are how to sustain the Kenyan flower-growing industry, on which European florists are so dependent (or, much better, how to avoid such an intercontinental dependence on commerce in perishable goods and nevertheless sustain local economies), how to replace direct political and business meetings with "virtual" interaction though video links, and how to sustain the arts and entertainment industry when venues cannot be reached by performers and their publics.

As a postscript, not all consequences of the Eyjafjallajökull crisis were negative. For example, a daily average of 206,465 tonnes of $\mathrm{CO}_{2}$ was saved by the flight ban, as the 150,000 tonnes emitted by the volcano were less than half of that produced by commercial aviation. Moreover, around London's major airports air and noise pollution levels were reduced very significantly for the duration of the ban (Barratt and Fuller 2010).

\section{Conclusion}

Several lessons emerge from this review of the Eyjafjallajökull eruption crisis. First, all national and international regulatory bodies need to make a more serious effort to evaluate the risks to civil aviation of volcanic eruptions. Scenarios should consider eruptive sequences that are longer and more catastrophic than the events of April 2010. They should consider the widest possible range of consequences of any such

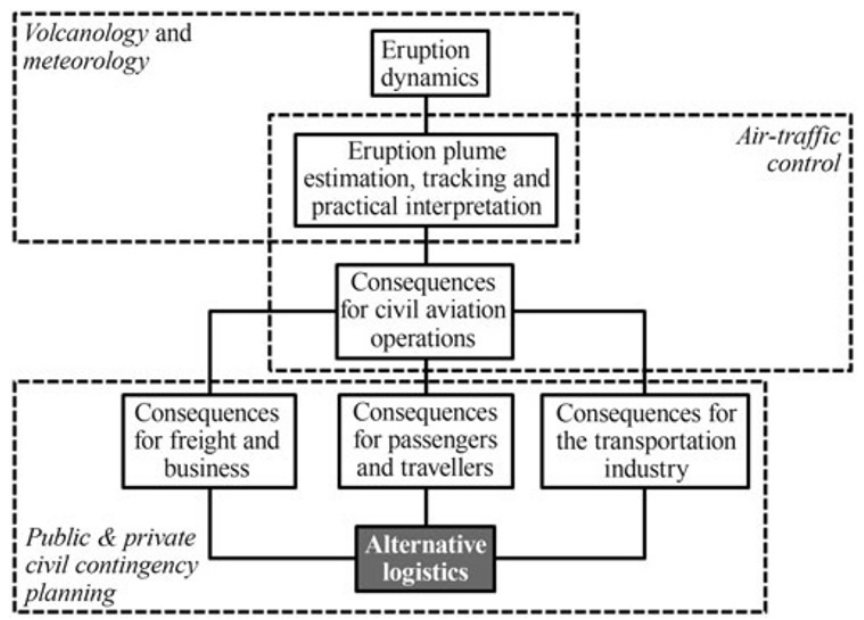

Figure 3. Schematic depiction of different competencies and responsibilities in managing a volcanic ash emergency for civil aviation

emergency, and also how the various agencies involved in the response should act together (Figure 3). Secondly, thresholds for safe flying should be more rigorously defined on the basis of evidence-based practice and in close relation to appropriate meteorological and geological remote sensing. Thirdly, international coordination and regulation of European airspace needs to be broadened to include, not merely services, competition rules and general accident prevention, but also natural hazard impacts. Fourthly, an integrated plan is needed at the European (i.e. pan-national) level for cases in which air travel needs to be substituted by other modes of transportation. These needed to be coordinated, price controls may need to be imposed and capacity should be increased temporarily. This must be achieved by prior planning. Fifthly, companies with significant international components need business continuity arrangements designed to manage situations in which travel and shipments by air cannot take place for some definable time period. Finally, simple risk aversion should not be a strategy in any future eruption scenario. It can lead to unnecessary hardship and bankruptcies and is in any case less efficient than management based upon proper risk assessment. One needs to remember that the potential for more and greater volcanic ash disruption of civil aviation remains high and therefore this is a hazard that will not go away in the long term.

\section{Note}

i Several countries, notably Finland, reported engine damage to fighter aircraft which flew during the ash emergency. The F16 fighter engine, for example, operates at higher intake volume and temperature than commercial jet engines. The influence of volcanic ash on propeller aircraft is not well documented. However, it is notable that Manila Airport in the Philippines remained open to such craft during the eruption of Pinatubo in 1991 (Casadevall, Delos Reyes, and Schneider 1999). 


\section{References}

Ajtai, N., H. I. Ştefănie, L. C. Stoian, and M. G. Oprea. 2010. The Volcanic Ash and Its Impact on European Air Transport Industry: A Case Study on the Detection and Impact of the Eyjafjallajökull Volcanic Ash Plume over North-Western Europe between 14th and 21st April 2010. AES Bioflux 2 (1): 57-68.

Albersheim, S., and M. Guffanti. 2009. The United States National Volcanic Ash Operations Plan for Aviation. Natural Hazards 51 (2): 275-285.

Alemanno, A. 2010. The European Regulatory Response to the Volcanic Ash Crisis: Between Fragmentation and Integration. European Journal of Risk Regulation No. 2: 101-106.

Alexander, D. E. 2002. Principles of Emergency Planning and Management. New York: Oxford University Press.

Arbuthnot, K. 2008. A Command Gap? A Practitioner's Analysis of the Value of Comparisons between the UK's Military and Emergency Services' Command and Control Models in the Context of UK Resilience Operations. Disaster Prevention and Management 18 (2): 186-194.

Barratt, B., and G. Fuller. 2010. Analysis of the Impact of Heathrow and Gatwick Airport Closures on Local Air Quality during the Eyjafjallajökull Eruption of 15th-17th April 2010. Geophysical Research Abstracts 12, EGU2010-15764, European Geophysical Union General Assembly, Vienna.

BBC News. 2010. Iceland Volcano: Why a Cloud of Ash Has Grounded Flights. 15 April 2010. http://www.bbc.co.uk/2/hi/science/nature/ 8621992.stm

Brannigan, V. M. 2010. Alice's Adventures in Volcano Land: The Use and Abuse of Expert Knowledge in Safety Regulation. European Journal of Risk Regulation No. 2: 107-113.

Brooker, P. 2010. Fear in a Handful of Dust: Aviation and the Icelandic Volcano. Significance 7 (3): 112-115.

Budd, L. C. S., S. Griggs, D. Howarth, and S. G. Ison. 2011. A Fiasco of Volcanic Proportions? Eyjafjallajökull and the Closure of European Airspace. Mobilities 6 (1): 31-40.

Button, K. 1996. Liberalising European Aviation: Is there an Empty Core Problem? Journal of Transport Economics and Policy 30 (3): 275-291.

Casadevall, T. J., ed. 1994a. Volcanic Ash and Aviation Safety. U.S. Geological Survey Bulletin 2047.

Casadevall, T. J. 1994b. The 1989-1990 Eruption of Redoubt Volcano, Alaska: Impacts on Aircraft Operations. Journal of Volcanology and Geothermal Research 62 (1-4): 301-316.

Casadevall, T. J., and M. D. Krohn. 1995. Effects of the 1992 Crater Peak Eruptions on Airports and Aviation Operations in the United States and Canada. In The 1992 Eruptions of Crater Peak Vent, Mount Spurr Volcano, Alaska, edited by T. E. C. Keith. U.S. Geological Survey Bulletin B2139: 205-220.

Casadevall, T. J., P. J. Delos Reyes, and D. J. Schneider. 1999. The 1991 Pinatubo Eruptions and Their Effects on Aircraft Operations. In Fire and Mud: Eruptions and Lahars of Mount Pinatubo, Philippines. United States Geological Survey. http://pubs.usgs.gov/pinatubo/ contents.html.

Eurocontrol. 2006. Main Report for the 2005/2012 Integrated Risk Picture for Air Traffic Management in Europe. EEC Note No. 05/06, Project C1.076/EEC/NB/05, Eurocontrol Experimental Centre, Brétigny-sur-Orge, France.

Eurocontrol. 2010. Volcanic Ash Cloud Timeline - April Events. http:// www.eurocontrol.int/corporate/public/standard page/volcanic ash cloud_chronology.html.

European Commission. 2010. Towards a Stronger European Disaster Response: The Role of Civil Protection and Humanitarian Assistance. Communication from the Commission to the European Parliament and Council. Brussels, 26 October 2010, COM(2010) 600 final.
European Court of Justice. 2013. Case C-12/11. Denise McDonagh v Ryanair: Volcanic Ash and "Super Extraordinary Circumstances." European Court of Justice Decision of 31 January 2013. http://www. eutopialaw.com.

European Union. 2004. Regulation (EC) No. 261/2004 of the European Parliament and of the Council of 11 February 2004 Establishing Common Rules on Compensation and Assistance to Passengers in the Event of Denied Boarding and of Cancellation or Long Delay of Flights, and Repealing Regulation (EEC) No. 295/91. Official Journal of the European Union, Brussels, 17.2.2004: L. 46/1-L46/7.

Flentje, H., H. Claude, T. Elste, S. Gilge, U. Köhler, C. Plass-Dülmer, W. Steinbrecht, W. Thomas, A. Werner, and W. Fricke. 2010. The Eyjafjallajökull Eruption in April 2010: Detection of Volcanic Plume Using in-situ Measurements, Ozone Sondes and Lidar-Ceilometer Profiles. Atmospheric Chemistry and Physics 10 (20): 10085-10092.

Gigerenzer, G. 2006. Out of the Frying Pan into the Fire: Behavioral Reactions to Terrorist Attacks. Risk Analysis 26 (2): 347-351.

Graham, R. V., and D. Young. 2006. Preparing an Initial Assessment of the SESAR Concept of Operations "EP3: Single European Sky Implementation Support through Validation". http://publish.eurocontrol. int/eec/gallery/content/public/documents/newsletter/2006/issue_3/ EP3\%20\%20APAC\%20October\%2020061.pdf.

The Guardian. 2010. Iceland Volcano - Row over Passengers' Costs as Thousands Still Stranded. 22 April 2010. http://www.guardian.co. uk/world/blog/2010/apr/22/iceland-volcano-compensation?INTCM $\mathrm{P}=\mathrm{SRCH}$.

The Guardian. 2013. Ryanair Facing Payout over Passengers Stranded by Volcanic Ash Cloud. 22 March 2012. http://www.guardian.co.uk/ business/2012/mar/22/ryanair-payout-stranded-ash-passengers.

Guffanti, M., T. J. Casadevall, and K. Budding. 2010. Encounters of Aircraft with Volcanic Ash Clouds: A Compilation of Known Incidents, 1953-2009. Data Series 545. U.S. Geological Survey, Reston, Virginia.

ICAO (International Civil Aviation Organization). 2007. Manual on Volcanic Ash, Radioactive Material and Toxic Chemical Clouds, 2nd edition. Montréal: International Civil Aviation Organization.

ICAO (International Civil Aviation Organization). 2010a. First Meeting of the International Volcanic Ash Task Force (IVATF), Montréal, Canada, 27-30 July 2010. International Civil Aviation Organization, Paris (six parts).

ICAO (International Civil Aviation Organization). 2010b. Volcanic Ash Contingency Plan, European and North Atlantic Regions. EUR Doc. 019, NAT Doc. 006, Part II. December 2010. International Civil Aviation Organization, Paris.

Jack, I. 2001. The Crash That Stopped Britain. London: Granta Books.

Jakosky, B. M. 1986. Volcanoes, the Stratosphere and Climate. Journal of Volcanology and Geothermal Research 28 (3-4): 247-255.

Jensen, O. B. 2011. Emotional Eruptions, Volcanic Activity and Global Mobilities: A Field Account from a European in the US during the Eruption of Eyjafjallajökull. Mobilities 6 (1): 67-75.

Jones, A., D. Thompson, M. Hort, and B. Devenish. 2007. The U.K. Met Office's Next-Generation Atmospheric Dispersion Model, NAME III. Air Pollution Modelling and Its Application 17 (6): 580-589.

Krotkov, N., A. Krueger, K. Yang, S. Carn, G. Vicente, E. Hughes, J. Joiner, R. Kahn, et al. 2010. Improving Capabilities of Satellite Monitoring of Volcanic Clouds: Lessons Learned from Eyjafjallajökull Eruption. Paper presented at the Atlantic Conference on Eyjafjallajökull and Aviation, 15-16 September 2010, Keflavik Airport, Iceland.

Leadbetter, S. J., and M. C. Hort. 2009. Volcanic Ash Hazard Climatology for an Eruption of Hekla Volcano, Iceland. Journal of Volcanology and Geothermal Research 199 (3-4): 230-241.

Mazzocchi, M., F. Hansstein, and M. Ragona. 2010. The 2010 Volcanic Ash Cloud and Its Financial Impact on the European Airline Industry. CESifo Forum No. 2: 92-100.

Melchers, R. E. 2001. On the ALARP Approach to Risk Management. Reliability Engineering and System Safety 71 (2): 201-208. 
Miller, T. P., and T. J. Casadevall. 2000. Volcanic Ash Hazards to Aviation. In Encyclopedia of Volcanoes, edited by H. Sigurdsson, 915-930. New York: Elsevier.

Newhall, C. G., and S. Self. 1982. The Volcanic Explosivity Index (VEI): An Estimate of Explosive Magnitude for Historical Volcanism. Journal of Geophysical Research 87 (C2): 1231-1238.

Nippani, S., and K. Washer. 2011. A Note on the Impact of the Eyjafjallajökull Volcanic Eruption on Airline Stocks. Southwestern Finance Association 50th Annual Conference, Houston, Texas, 2011. http:// www.southwesternfinance.org.

Romero, R. 2004. The International Airways Volcano Watch (IAVW). Proceedings of the Second International Conference on Volcanic Ash and Aviation Safety, Alexandria, Virginia, Office of the Federal Coordinator for Meteorological Services and Supporting Research, $1-10$.

Sammonds, P., B. McGuire, and S. Edwards, eds. 2010. Volcanic Hazard from Iceland: Analysis and Implications of the Eyjafjallajökull Eruption. Institute for Risk and Disaster Reduction, University College London, London.

Scanlon, T. J. 2003. Helping the Other Victims of September 11: Gander Uses Multiple EOCs to Deal with 38 Diverted Flights. International
Journal of Mass Emergencies and Disasters 20 (3): 369-398, and Australian Journal of Emergency Management 18 (2): 108-121.

Scarone, H. 1987. Volcanic Ash Clouds: A Continuing Threat to International Aviation. Earthquakes and Volcanoes 19 (2): 65-73.

Schoemaker, P. J. H. 1993. Multiple Scenario Development: Its Conceptual and Behavioural Foundation. Strategic Management Journal 14 (3): 193-213.

Schubert, F. 2003. The Single European Sky: Controversial Aspects of Cross-Border Service Provision. Air and Space Law 28 (1): 32-49.

Siebert, L., T. Simkin, and P. Kimberly. 2010. Volcanoes of the World, 3rd edition. Berkeley: University of California Press.

Sigurdsson, H., ed. 1999. The Encyclopedia of Volcanoes. Orlando: Academic Press.

UK Cabinet Office. 2010. National Risk Register of Civil Emergencies. Government of the United Kingdom, London.

Viscusi, W. K. 2010. The Heterogeneity of the Value of Statistical Life: Introduction and Overview. Journal of Risk and Uncertainty 40 (1): $1-13$.

Witham, C., H. Webster, M. Hort, A. Jones, and D. Thomson. 2012. Modelling Concentrations of Volcanic Ash Encountered by Aircraft in Past Eruptions. Atmospheric Environment. 48: 219-229.

Open Access This article is distributed under the terms of the Creative Commons Attribution License which permits any use, distribution, and reproduction in any medium, provided the original author(s) and source are credited. 